\title{
Analysis Conextivity Sidewalk Design In Tasikmalaya School Area
}

\author{
Yogi Arisandi ${ }^{1}$ Khusnul Khotimah ${ }^{2}$ \\ ${ }^{I}$ Politeknik Transportasi Darat Indonesia-STTD, Cibitung No.9 Bekasi and Postcode, Indonesia \\ ${ }^{2}$ Balitbanghub, Merdeka Timur, Jakarta and Postcode, Indonesia
}

\section{ARTICLE INFO}

\begin{tabular}{l} 
AIJ use only: \\
Received date : 30 May 2020 \\
Revised date : 15 June 2020 \\
Accepted date : 20 July 2020 \\
\hline Keywords: \\
Sidewalk \\
School Area \\
Pedestrian Conextivity \\
Design Conextivity
\end{tabular}

\section{AIJ use only:}

\section{Keywords:}

School Area

Design Conextivity

\begin{abstract}
A B S T R A C T
In some areas of Tasikmalaya, there is an education zone. Conditions in the zone, some students are forced to walk on the road because of the unavailability of sidewalks or dealing with the traffic vehicles passing by and very unfriendly to school children. To improve the safety, comfort and safety of pedestrian users, it is necessary to plan the needs of integrated pedestrian facilities in Tasikmalaya Regency. This study using pedestrian analysis method that is done on sidewalk and pedestrian way and method of alignment analysis. It was found that the volume of vehicles $>1000$ vehicles / 12 hours and pedestrian volume> 300orang / 12 hours. Pedestrian facilities such as sidewalks are indispensable in the education zone of Tasikmalaya Regency to minimize conflicts (vehicles and pedestrians). In one of the research sites, namely on Jl. K. H. Zaenal Musthafa requires pelican crossing because of the huge volume of vehicles and the very high volume of pedestrians. Integrated pedestrian concept is done by connecting J1. Paledang with Jl. Garut-Tasikmalaya, Jl. Bantar Payung- Jl.GarutTasikmalaya.
\end{abstract}

\section{INTRODUCTION}

Currently in Tasikmalaya Regency as mandated by Law no. 22 of 2009 on Road Traffic and Transportation and Presidential Instruction No. 4 of 2013 on the Road Safety Action Decade Program, requires the government to provide policies for the safety of its citizens.

The purpose of this research is to know the requirement of pedestrian facility at research location in Tasikmalaya Regency which is safe, comfortable, and humane so as to fulfill the needs of pedestrian users both in terms of number and standard of its provider.

* Corresponding author.

E-mail address: slich@yahoo.com

Article with open access under license

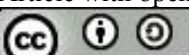

Besides, in this research, the planning of integration between the pedestrian paths so that the linkage of pedestrian paths to the building structure, the accessibility of the environment, and the transportation system

\section{METHOD}

\section{Location and Time of Study}

The research location in this study is Tasikmalaya Regency, West Java. This research was conducted in 2019 for 3 months.

\section{Method of Collecting Data}

\section{Primary Data}

The primary data collection method in this study was observing and surveying the field. Primary data in this research are as follows. 
Survey of school location inventory;

Car traffic enumeration survey; and

Pedestrian traffic surveys survey.

\section{Secondary Data}

Secondary data collection method in this research is to take the required data in relevant agencies and search for various sources relevant to the research topic.

\section{Survey Method}

\section{Survey of school location inventory}

The school site inventory survey was conducted by walking along the road segments in Tasikmalaya District and determining the location of schools that have direct access to roads.

\section{Survey of traffic enumeration}

The vehicle traffic enumeration survey was conducted on road segments that were direct access from school locations. Survey conducted at 06.00-07.00 where in that time period is the peak time of school children to go to school location.

\section{Pedestrian traffic surveys survey}

Pedestrian traffic surveys are conducted at school location points. The survey was conducted to obtain pedestrian data that travels across and across the street. Survey conducted at 06.00-07.00 where in that time period is the peak time of school children to go to school location.

\section{Analysis Method}

\section{Pedestrian Analysis Method}

\section{a. Sidewalk}

Sidewalks can be directed to roads with a pedestrian volume of more than 300 people per 12 hours (06.00-18.00) and more than 1,000 kendraan vehicles per 12 hours (06.00-18.00). The pavement free space is not less than 2.5 meters and the free depth is not less than 1 meter. Side freedom is not less than 0.3 meters. Planning of the installation of utilities other than having to meet the pavement free space must also comply with the provisions in the user manual for the installation of the utility.

The width of the sidewalk should be able to serve the volume of existing pedestrians. The minimum width of the sidewalk can be seen in the table below.

Table 1. The minimum width of the sidewalk

\begin{tabular}{cccc}
\hline \multicolumn{2}{c}{$\begin{array}{c}\text { Classification of } \\
\text { Road Plans }\end{array}$} & $\begin{array}{c}\text { Min } \\
\text { Standard. (m) }\end{array}$ & $\begin{array}{c}\text { Min.Width } \\
\text { (Exception) }\end{array}$ \\
\hline Type & Class I & 3,0 & 1,5 \\
\hline & Class II & 3,0 & 1,5 \\
\hline & Class III & 1,5 & 1,0 \\
\hline
\end{tabular}

Perkotaan, 1995

\section{Information :}

Minimum width is used on bridges of 50 meters or more in tunnels where the volume of pedestrian traffic is 300500 persons per 12 hours.

\section{b. Crossing Facility}

Pedestrian crosswalk facilities are closely related to the sidewalk, then pedestrian crossing facilities can be a sidewalk extension. For crossings with zebra cross and pelican crossing should be placed as close as possible to the intersection. The location of the crossing must be clearly visible to the rider and placed perpendicular to the axis of the road.

The basis for determining the type of ferry facilities is as follows:

Table 2. Crossing Facilities Based on $\mathrm{PV}^{2 *}$

\begin{tabular}{|c|c|c|c|l|}
\hline No. & $\mathbf{P V}^{\mathbf{2}}$ & $\mathbf{P}$ & $\mathbf{V}$ & \multicolumn{1}{|c|}{ Rekomendation } \\
\hline 1 & $>10^{8}$ & $50-1100$ & $300-500$ & Zebra Cross \\
\hline 2 & $>2 \times 10^{8}$ & $50-1100$ & $400-750$ & Zebra Cross wit a waiting rack \\
\hline 3 & $>10^{8}$ & $50-1100$ & $>500$ & Pelican \\
\hline 4 & $>10^{8}$ & $>1100$ & $>300$ & Pelican \\
\hline 5 & $>2 \times 10^{8}$ & $50-1100$ & $>750$ & Pelican with a waiting rack \\
\hline 6 & $>2 \times 10^{8}$ & $>1100$ & $>400$ & Pelican with a waiting rack \\
\hline
\end{tabular}




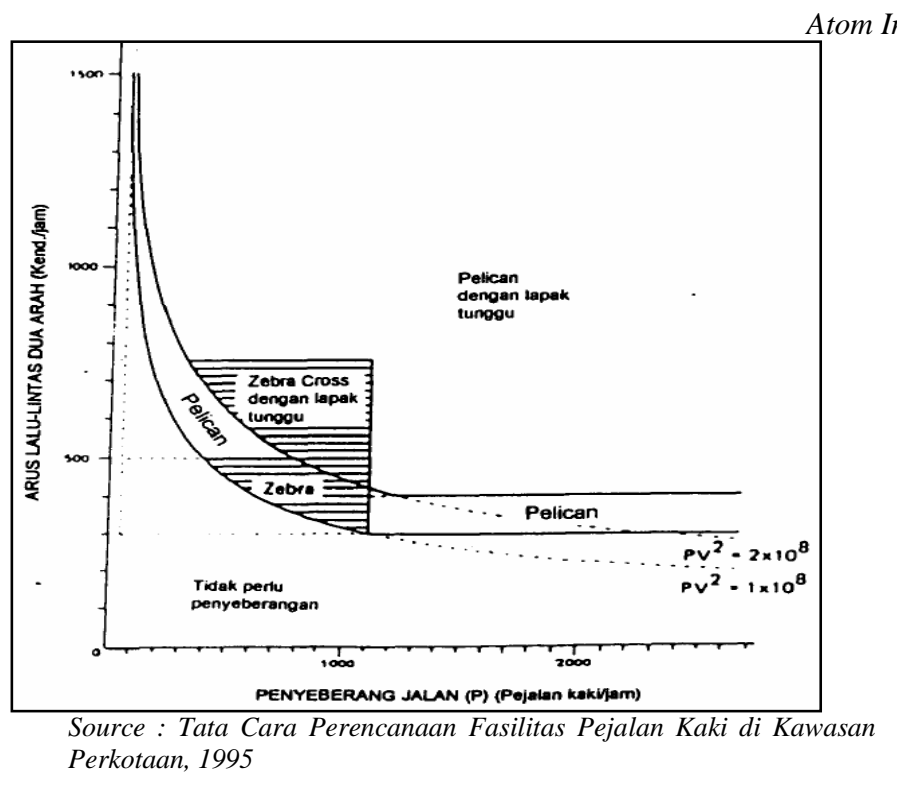

Picture 1. Dasar penentuan fasilitas penyeberangan berdasarkan $\mathrm{PV}^{2}$

\section{Conextivity Analysis Method}

The integrity analysis is used to obtain optimal results in the planning of pedestrian facilities that are connected between the pedestrian path to the structure of the building, the accessibility between environments, and the transportation system. The concept of integration is assessed through its connectivity index. The area of pedestrian ups and downs connected by a complex network of pedestrian facilities means having a high spatial interaction pattern. To know the strength of interaction of a region is used index of connectivity which is formulated as follows:

$$
\alpha=-------
$$

Description:

$\alpha=$ connectivity index

$\mathrm{e}=$ number of pedestrian networks

$\mathrm{v}=$ number of pedestrians / pull of a pedestrian

\section{RESULTS AND DISCUSSION}

\section{Research sites}

The location of the research based on the survey of school location inventory that has been done is as follows:

1. SD Negeri 3 Mangunreja on Jl. Paledang;

2. SD Negeri Cintawana on Jl. Peledang;

3. SD Negeri 1 dan 2 Cipakat on Jl. K. H. Zaenal Musthafa;

4. SMA Negeri 1 Singaparna on Jl. K. H. Zaenal Musthafa;

5. SMP Negeri Padakembang and SD Negeri 3 Cisaruni on Jl. Bantarpayung;
6. SD Negeri 2 Cintaraja on Jl. Raya Cintaraja;

7. SD Negeri 1 Cintaraja and SD Negeri 1 Cikunir on Jl. Raya Singaparna;

\section{Vehicle Volume}

Vehicle traffic enumeration surveys are divided into 3 types of vehicles, namely light vehicles (LV), heavy vehicles (HV), and motorcycles (MC). Based on the traffic survey results that have been done, it can be seen that the volume of vehicles on each road segment is relatively large. Motorcycles are the most vehicles (dominating) the volume of vehicles on each road segment at the study site. In addition, it can be seen that the volume of heavy vehicles (buses and trucks) has considerable volumes on several streets at the survey sites. Vehicle volume based on vehicle traffic survey can be seen in the table below.

Table 3. Vehicle volume

\begin{tabular}{|c|c|c|c|}
\hline \multirow{2}{*}{ No. } & \multirow{2}{*}{ Street Name } & \multicolumn{2}{|c|}{ Arus Total } \\
\hline & & Veh./12Hours & smp/12Hours \\
\hline \multirow[t]{3}{*}{1} & \multicolumn{3}{|l|}{ Jl. Paledang } \\
\hline & West & 2856 & 1909.95 \\
\hline & East & 2627 & 1751 \\
\hline \multirow[t]{3}{*}{2} & \multicolumn{3}{|c|}{ Jl. K.H. Zaenal Musthafa } \\
\hline & North & 3613 & 2368.1 \\
\hline & South & 9911 & 6233.9 \\
\hline \multirow[t]{3}{*}{3} & \multicolumn{3}{|l|}{ Jl. Bantarpayung } \\
\hline & North & 4310 & 2429.3 \\
\hline & South & 4565 & 2528.75 \\
\hline \multirow[t]{3}{*}{4} & \multicolumn{3}{|l|}{ Jl. Raya Cintaraja } \\
\hline & West & 9512 & 6960.65 \\
\hline & East & 2151 & 1615 \\
\hline \multirow[t]{3}{*}{5} & \multicolumn{3}{|l|}{ J1. Raya Singaparna } \\
\hline & North & 11883 & 6417.5 \\
\hline & South & 10778 & 5809.75 \\
\hline
\end{tabular}

\section{Walking Volume}

Based on the results of the survey that has been done, it can be seen that the number of pedestrians is relatively large on some roads in the study sites. However, there is an enormous volume of pedestrians on K. H. Zaenal Musthafa road. This is because the segment Jl. K. H. Zaenal Musthafa is not only a school location, but there are residential areas that have direct access to highways and office locations.

Table 4. Pedestrian volume 


\begin{tabular}{clcc}
\hline & & \multicolumn{2}{c}{$\begin{array}{c}\text { Pedestrian (people / } \\
\text { 12hours) }\end{array}$} \\
\cline { 3 - 4 } No & Street Name & Cross & $\begin{array}{c}\text { Down the } \\
\text { road }\end{array}$ \\
\hline 1 & Jl. Paledang & 350 & 412 \\
\hline 2 & Jl. K.H. Z. Musthafa & 4100 & 2234 \\
\hline 3 & Jl. Bantarpayung & 841 & 902 \\
\hline 4 & Jl. Raya Cintaraja & 648 & 639 \\
\hline 5 & Jl. Raya Singaparna & 166 & 333 \\
\hline Source : Survey results, 2019 & &
\end{tabular}

\section{Recap of Survey Results}

The survey results and calculations made can be used as a basis for planning pedestrian facilites in the form of sidewalks. Sidewalks can be directed to roads where there are more than 300 pedestrian volumes per 12 hours (06.00-18.00) and vehicle volume of over 1,000 vehicles per 12 hours (06.0018.00).

To make it easier to read the survey results data, then created a recap of the survey results to determine the volume of vehicles and pedestrians on each road segment at the study site. Recap of survey results are as follows.

Table 5. Recap survey results

\begin{tabular}{cccccc}
\hline & & $\begin{array}{c}\text { Vehicle } \\
\text { Volume }\end{array}$ & \multicolumn{4}{c}{$\begin{array}{c}\text { Pedestrian } \\
\text { No. }\end{array}$} & $\begin{array}{c}\text { Name of } \\
\text { Street }\end{array}$ & \multicolumn{3}{c}{$\begin{array}{c}\text { Down } \\
\text { (veh/12Hours) }\end{array}$} & Cross & $\begin{array}{c}\text { The } \\
\text { Road }\end{array}$ & Total \\
\cline { 4 - 6 } & & 5.483 & 350 & 412 & 762 \\
\hline 1 & Jl. Paledang & 13.524 & 4.1 & 2.234 & 6.33 \\
\hline \multirow{2}{*}{2} & $\begin{array}{l}\text { Jl. K.H. } \\
\text { Zaenal } \\
\text { Musthafa }\end{array}$ & 8.874 & 841 & 902 & 1.74 \\
\hline 3 & $\begin{array}{l}\text { Jl. } \\
\text { Bantarpayung }\end{array}$ & 11.662 & 648 & 639 & 1.29 \\
\hline 4 & $\begin{array}{l}\text { Jl. Raya } \\
\text { Cintaraja }\end{array}$ & 22.661 & 166 & 333 & 499 \\
\hline 5 & $\begin{array}{l}\text { Jl. Raya } \\
\text { Singaparna }\end{array}$ & & & & \\
\hline Source : Survey Results and Calculation, 2019 &
\end{tabular}

Based on the results of the survey and the calculation, it can be seen that all roads in the study sites have a very large vehicle volume and almost all research sites have a vehicle volume of more than 1,000 kend./12 hours.

Neither with the volume of pedestrians can be seen in the above table an average of more than 300 pedestrians per 12 hours.

Based on the above description, it is necessary pedestrian facilities in the form of sidewalks on all roads in the research location because based on survey results and calculations, the sidewalks can be applied to all research sites.

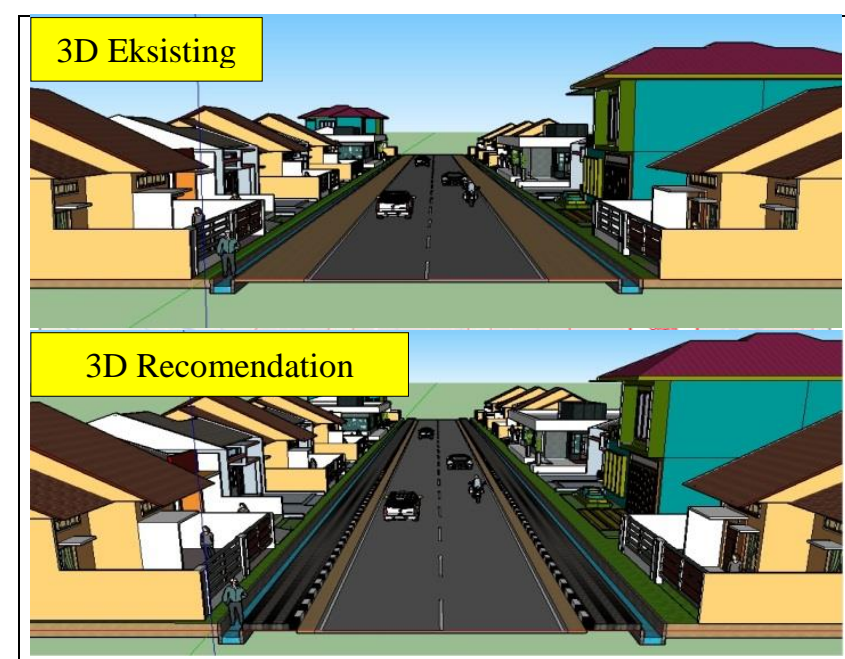

Design of the sidewalk on Jl. Paledang

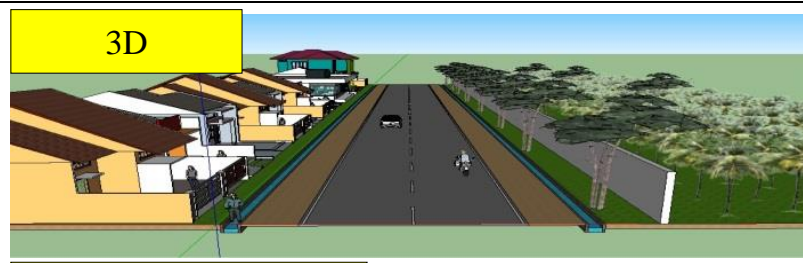

3D Recomendation

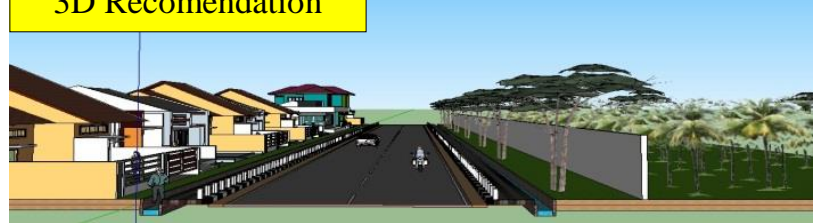

Design of the sidewalk on Jl. Bantarpayung

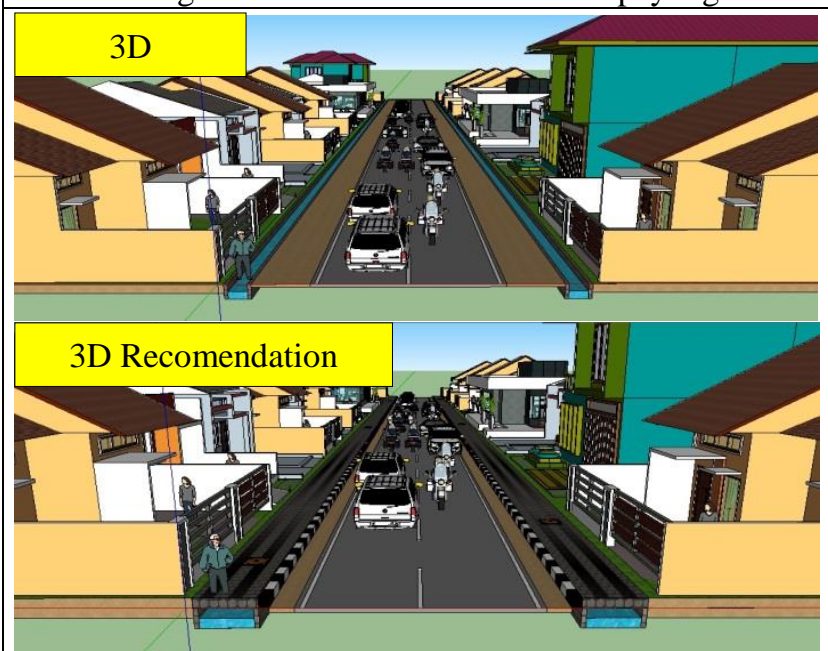

Design of the sidewalk on Jl.KH.Zaenal Musthafa
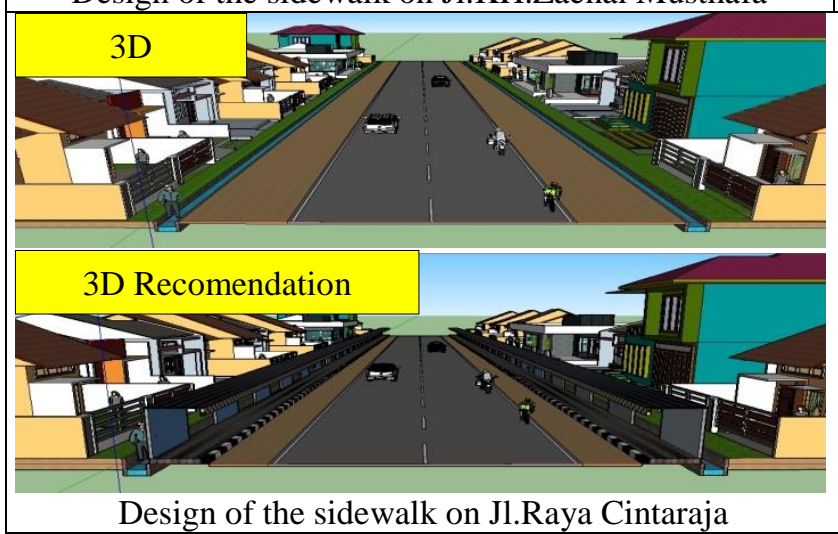


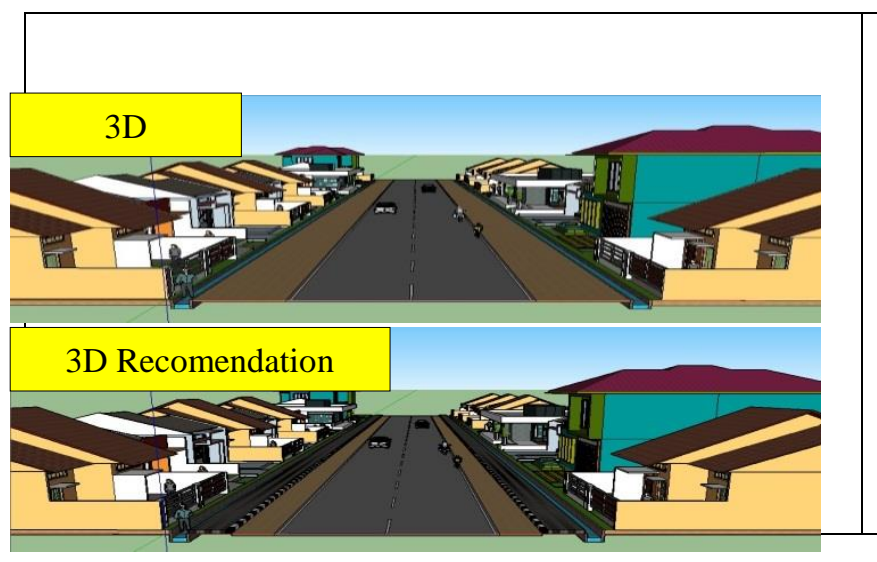

Picture 2. Proposed Sidewalk at Research Sites

\section{Recommended Crossing Facilities}

Ferry facilities are incomplete because the ferry facilities are no less important facilities in ensuring pedestrian safety. Recommended ferry facilities are determined based on the number of crossers and the volume of vehicles. Recommended ferry facilities can be seen in the table below.

Table 6. Recommended Cross Facilities

\begin{tabular}{lcccc}
\hline Nama Jalan & $\mathbf{P}$ & $\mathbf{V}$ & $\mathbf{P V}^{\mathbf{2}}$ & $\begin{array}{c}\text { Rekomend } \\
\text { ation }\end{array}$ \\
\hline Jl. Paledang & 40 & 645 & 16.641 .000 & Zebra Cross \\
\hline $\begin{array}{l}\text { Jl. K.H. Zaenal } \\
\text { Musthafa }\end{array}$ & 468 & 1591 & 1.184 .639 .508 & $\begin{array}{c}\text { Pelican } \\
\text { Crossing }\end{array}$ \\
\hline Jl. Bantarpayung & 96 & 1044 & 104.633 .856 & Zebra Cross \\
\hline Jl. Raya Cintaraja & 74 & 1372 & 139.296 .416 & Zebra Cross \\
\hline $\begin{array}{l}\text { Jl. Raya } \\
\text { Singaparna }\end{array}$ & 19 & 2666 & 135.043 .564 & Zebra Cross \\
\hline $\begin{array}{l}\text { Source : Results of data processing, 2019 } \\
\text { Sol }\end{array}$ & &
\end{tabular}

Based on the results of data processing mentioned above, the majority of recommended crossing facilities is Zebra Cross. However, there is one segment that requires pelican crossing, which is on Jl. K. H. Zaenal Musthafa because of its high pedestrian activity and large vehicle volume.

\section{Accesibility of Pedestrian Facility}

The concept of pedestrian alignment theory is used in order to make pedestrian facility planning more convenient for its users.

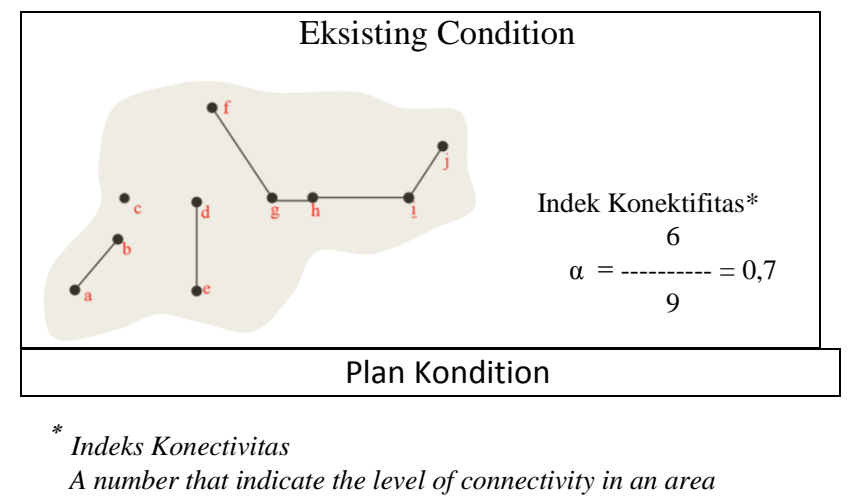

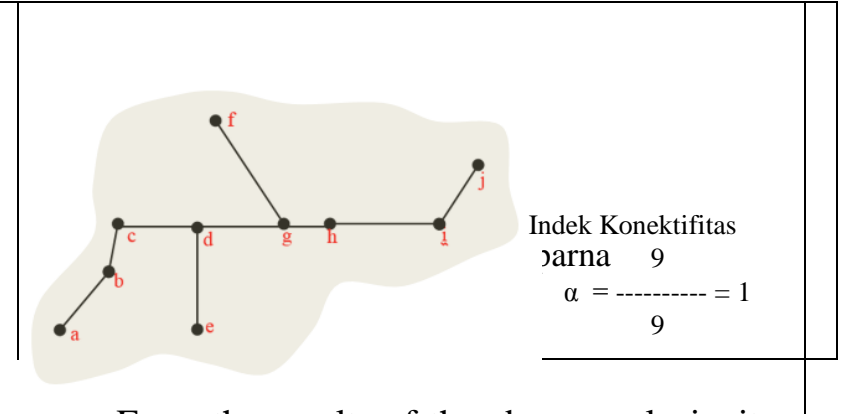

From the results of the above analysis, it can be concluded connectivity of pedestrian integration between areas of pedestrian rise/pull in Tasikmalaya Regency education zone to be better than before. By connecting Jl. Paledang with Jl. Garut-Tasikmalaya, Jl. Bantar Payung- Jl.Garut-Tasikmalaya.

\section{CONCLUSION}

Based on the results of surveys and data processing that has been done, it can be seen that the research location in Tasikmalaya Regency has a large volume of vehicles and not a few heavy vehicles (buses and trucks) that cross the road on the study site. It is because the road segment at the research location is the main route for freight transport to travel from and to other cities/districts. Therefore, pedestrian facilities such as sidewalks and pedestrian facilities are necessary to separate vehicular traffic with pedestrian activity to minimize conflicts (vehicles and pedestrians). In one of the research sites, namely on Jl. K. H. Zaenal Musthafa needs a pelican crossing because of the huge volume of vehicles and the very high pedestrian volume because there are many travel rides for pedestrians at that location (schools, offices, and settlements).

\section{REFERENCES}

Direktorat Jenderal Bina Marga. (1995). Tata Cara Perencanaan Fasilitas Pejalan Kaki di Kawasan Perkotaan. Jakarta: Ditjen Bina Marga, Kementerian PU.

Direktorat Bina Sistem Lalu Lintas dan Angkutan Kota. (1999). Pedoman Perencanaan dan Pengoperasian Lalu Lintas di Wilayah Perkotaan. Jakarta: Direktorat BSTP, Ditjen Perhubungan Darat

Republik Indonesia. (2009). Undang-Undang No. 22 Tahun 2009 Tentang Lalu Lintas dan Angkutan Jalan. Jakarta.

Republik Indonesia. (2013). Instruksi Presiden No. 4 Tahun 2013 Tentang Program Dekade Aksi keselamatan Jalan. Jakarta.

Anggriani, N ( 2009). Pedestrian Ways Dalam Perancangan Kota. Klaten: Yayasan Humaniora

Ewing, R (2019). Pedestrian and Transit Oriented Design. Broche: Urban Land Institute

Nazir, M. (2005). Metodologi Penelitian. Roonr Thalia Indonesia. 
Munawar, A (2004). Manajemen Lalu Lintas Perkotaan. Jogjakarta: Beta Offset Nacto (2013). Urban Street Design Guide. Washington: IslandPress
Tanan, N (2011). Fasilitas Pejalan Kaki. Bandung: Pusjatan 